\title{
Land Reallotment over the Course of the Development of a Rural Settlement in Ukraine
}

\begin{abstract}
The study is dedicated to land reallotment in the course of land use alteration in Ukraine. The case of the development of an individual residential block in an agricultural area is considered. The issue of the alteration of the spatial characteristics of land plots and changes in their designated use have been highlighted. The objective of the article is the substantiation of land reallotment at the level of an individual residential block on agricultural land which is privately owned by a number of landowners. The preconditions for the development of land reallotment in a rural-type settlement in the suburban area of a big city have been substantiated. Alternative approaches to land reallotment have been suggested. A comparative analysis of the suggested approaches and their practical approbation have been carried out. The change of land plot spatial characteristics in the course of reallotment by means of various reallotment scenarios has been analysed. Land plot value after reallotment in each scenario has been specified. The practicability of each approach depending on the initial conditions has been substantiated. The research can be used in the course of rural settlement development planning, the coordination of measures on land use type alteration with landowners and land users, with private landowners or the implementation of local community initiatives.
\end{abstract}

Keywords: land reallotment, agricultural land, sustainable development, rural settlement, land consolidation

Received: 5 March 2021; accepted: 26 April 2021

(C) 2021 Authors. This is an open access publication, which can be used, distributed and reproduced in any medium according to the Creative Commons CC-BY 4.0 License.

1 The Institute of Land Management of National Academy of Agrarian Sciences of Ukraine, Department of Problems of Land Development and Land Cadastre, Ukraine, email: mykola.malashevskyi@gmail.com, ORCID ID: https://orcid.org/0000-0001-7171-8835

2 National University of Life and Environmental Sciences of Ukraine, Geodesy and Cartography Department, Ukraine, email: kovalchukip@ukr.net, ORCID ID: https://orcid.org/0000-0002-2164-1259

3 National University of Life and Environmental Sciences of Ukraine, Geodesy and Cartography Department, Ukraine, email: olenamalashevska@gmail.com, ORCID ID: https://orcid.org/0000-0002-5387-5674 


\section{Introduction}

Spatial land improvement is one of the key instruments in the sustainable development of a territory [1, 2]. It has been affirmed by a body of research connected with agricultural land consolidation [3, 4], built-up area readjustment [5-7], and forestry land consolidation [8,9]. Land reallocation is predefined as the key constituent of such measures, land reallocation approaches are extensively examined in terms of land consolidation improvement [10-12]. Considerable attention has been paid to land plot exchange $[13,14]$. Cases of land reallotment predefined by the alteration of land use type are of particular interest.

Most spatial development measures in rural settlements are connected with the challenge of the alteration of land use type, which is in most cases predefined by the adaptation to social, economic, and environmental conditions. It results in interest in the economic benefits of land plot use, the formation of the environmentally safe land tenure, nature conservation, and the creation of a convenient living space.

The most widespread examples are: construction and reconstruction of transportation infrastructure [15], moving the industrial facilities from the city center into suburban area, development of municipal facilities (cemeteries, waste deposits, etc. [16]) and placement of environmental facilities [17]. Cases of land distribution for residential development as the result of land tenure conflicts and measures on the settlement improvement are especially noteworthy [17]. Land consolidation is considered to be an alternative to land acquisition [18] in the case of the placement of infrastructure facilities or resolution of land use conflicts [19].

At the same time, there are other land reallotment tasks caused by land use type alteration. The article is dedicated to the substantiation of land reallotment at the level of the construction of a residential block (homestead development) on agricultural land which is privately owned by a number of landowners. According to the sustainable development objectives of the territory, such land masses should change their spatial characteristics with the alteration of the designated use of the land plot. The paper stipulates the examination of preconditions, specification of possibilities and provision of practical recommendations on the technical aspects of land plot reallotment.

\section{Materials and Methods}

\subsection{Land Reallotment with the Alteration of Land Use Type}

In Ukraine, one of the most wide-spread cases is the alteration of the designated use of a land plot from personal agriculture to homestead development. Internal migration is one of key reasons for the settlements and built-up areas expansion.

In Ukraine, the total population is constantly decreasing, however, the growth of the urban population (Fig. 1) and that of Kyiv Region suburban rural-type settlements is observed (Fig. 2). Residential blocks are being built on agricultural land. 


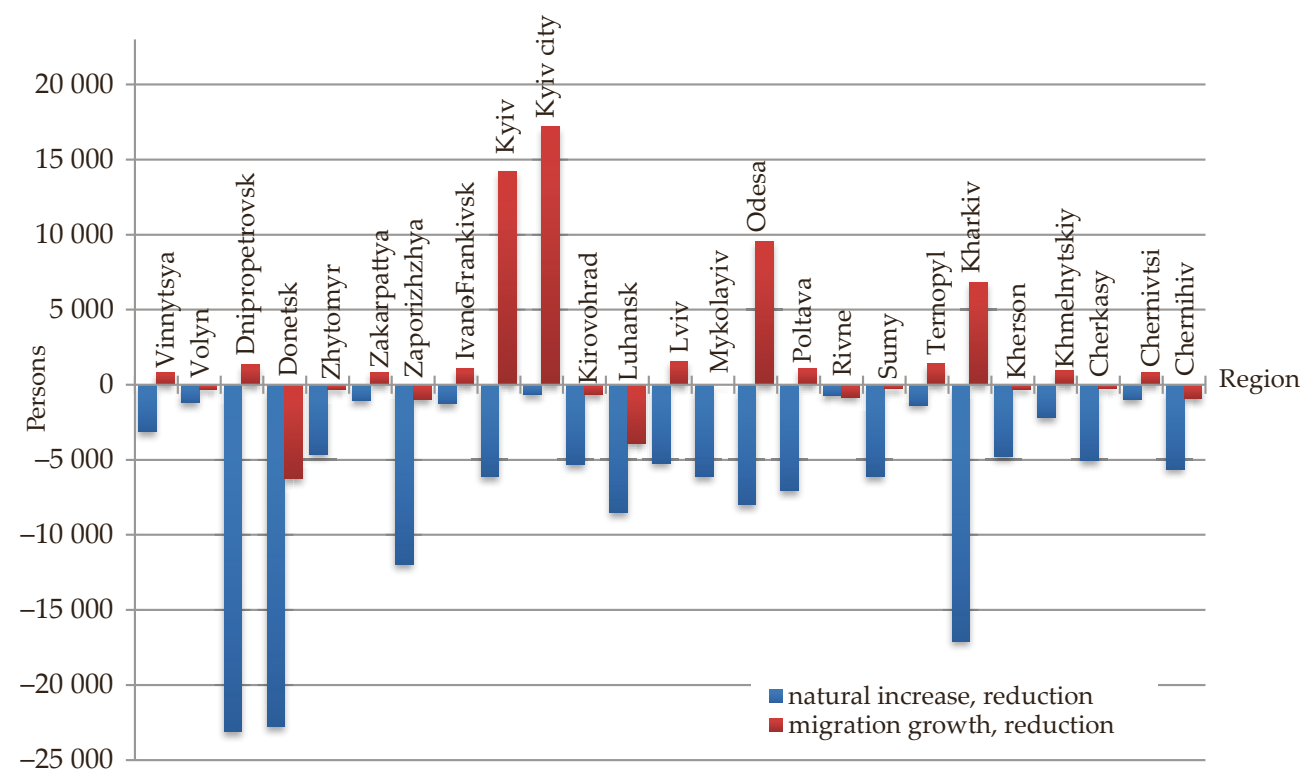

Fig. 1. Urban population, Ukraine, 2020 as compared to 2019 Source: created by data [20]

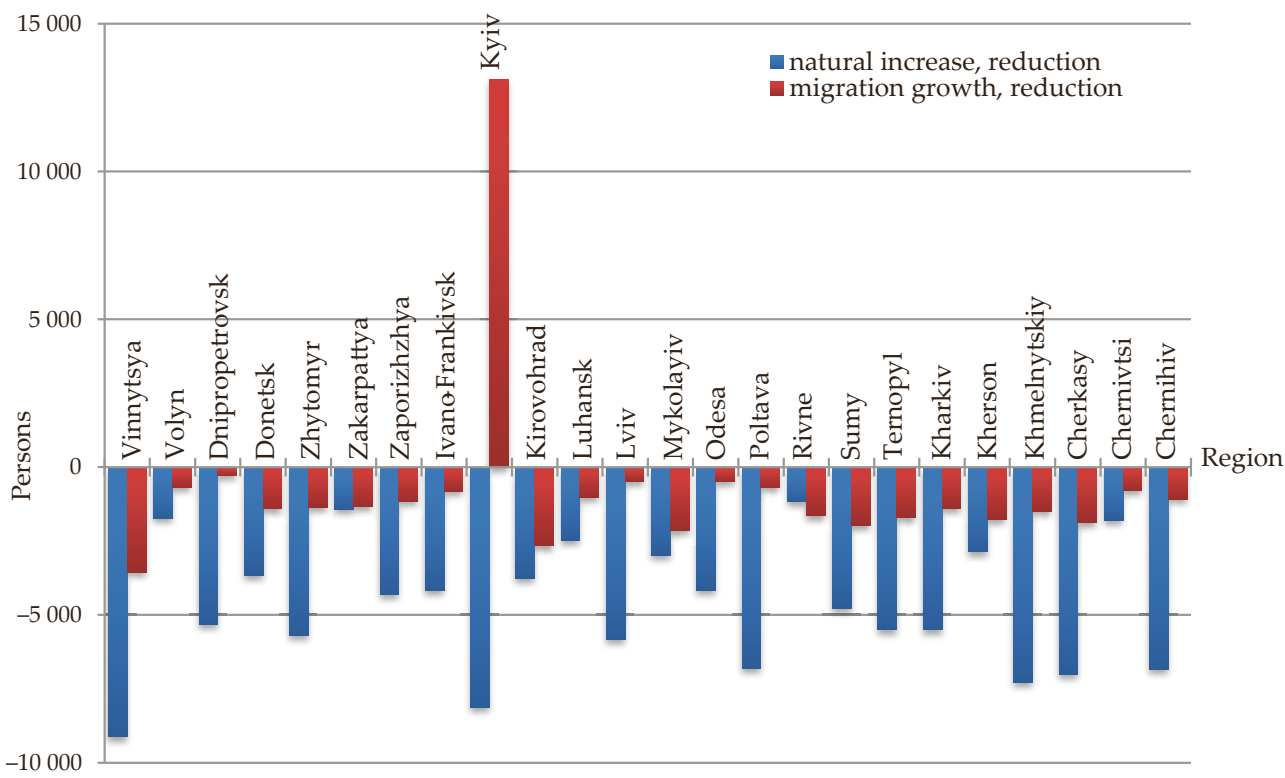

Fig. 2. Rural population, Ukraine, 2020 as compared to 2019 Source: created by data [20] 
As a rule, the land to be developed is owned by a number of private individuals. Land masses have the area of approximately $300,000 \mathrm{~m}^{2}$, include land plots of $800-3000 \mathrm{~m}^{2}$ and field tore roads with a width of approximately $5 \mathrm{~m}$. Each land plot has access to it.

With the alteration of land use type, the spatial characteristics of the land plots of private individuals should be considered and infrastructure facilities should meet the rational use requirements of the new designated use (in this case - development). They are the following: area, configuration and placement, which should allow the erection and maintenance of the building, and the provision of the necessary road network.

In Ukraine, the alteration of land plot use type is conducted in alignment with the urban planning documentation for the respective area in accordance with the legislation in effect. Land plot reallotment is carried out in accordance with the Land Code of Ukraine [21] and The Law of Ukraine on Land Management [22]. At the current stage, the hearing, reviewing and expansion of the draft law stipulating land consolidation in Ukraine is in progress [23]. The technical aspect of reallotment is scrutinized in the research.

The reallotment substantiation is conducted on the example of a typical agricultural land mass in Kyiv Region, the territory of which is to be developed.

The territory to be developed has no restrictions in terms of the reallotment of land plots due to the placement of buildings and reimbursement of their value. Land plots within the mass have the area of $800-2969 \mathrm{~m}^{2}$ (Fig. 3). In order to present the research results, land plots have been marshalled by area using standard deviation. The midpoint of the mean range is set as the average area.

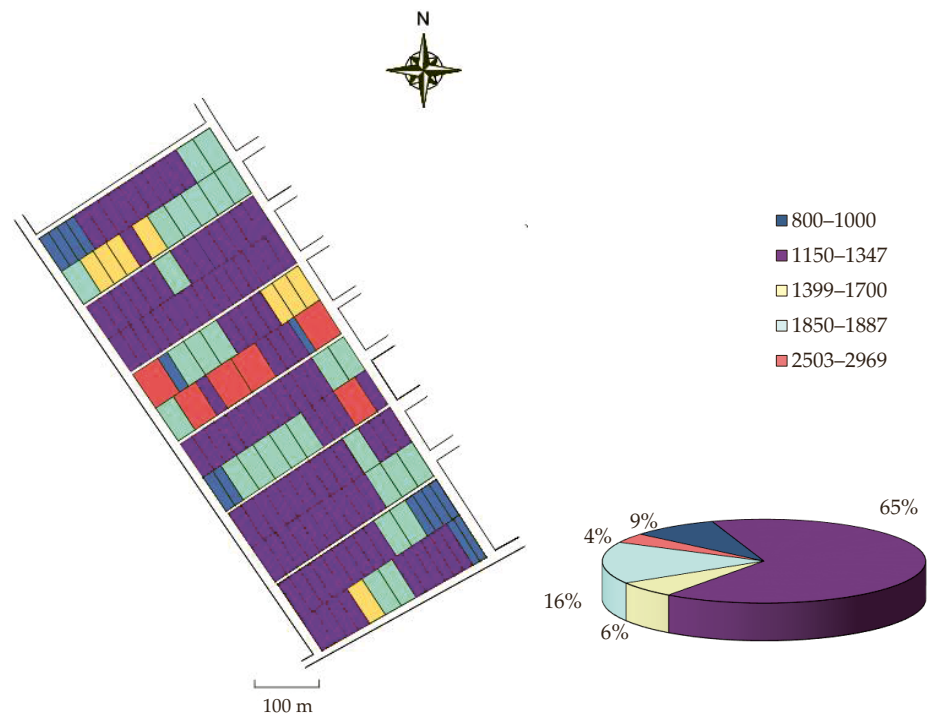

Fig. 3. Project territory land plots areas $\left[\mathrm{m}^{2}\right]$ 
Field roads within the land mass are unconstructed and have a width of $5 \mathrm{~m}$, the total area of land under the roads is $10,561 \mathrm{~m}^{2}$.

With the formation of a residential area, transport services should be provided by local streets. According to regulations in effect, these streets should have a width

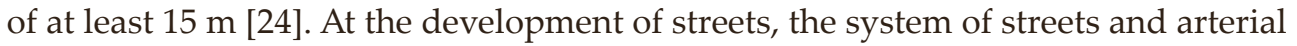
roads around the territory should be considered and access to each land plot should be provided. According to specifications in effect, local streets have a straight line camber, two traffic lanes with the width of $3 \mathrm{~m}$ each, green planting zones with a width of $1.5 \mathrm{~m}$ and sidewalks with a width of $1.5 \mathrm{~m}$ (Fig. 4). Sidewalks have a $2 \%$ single slope camber towards the pavement. The pavement camber is $2 \%$.

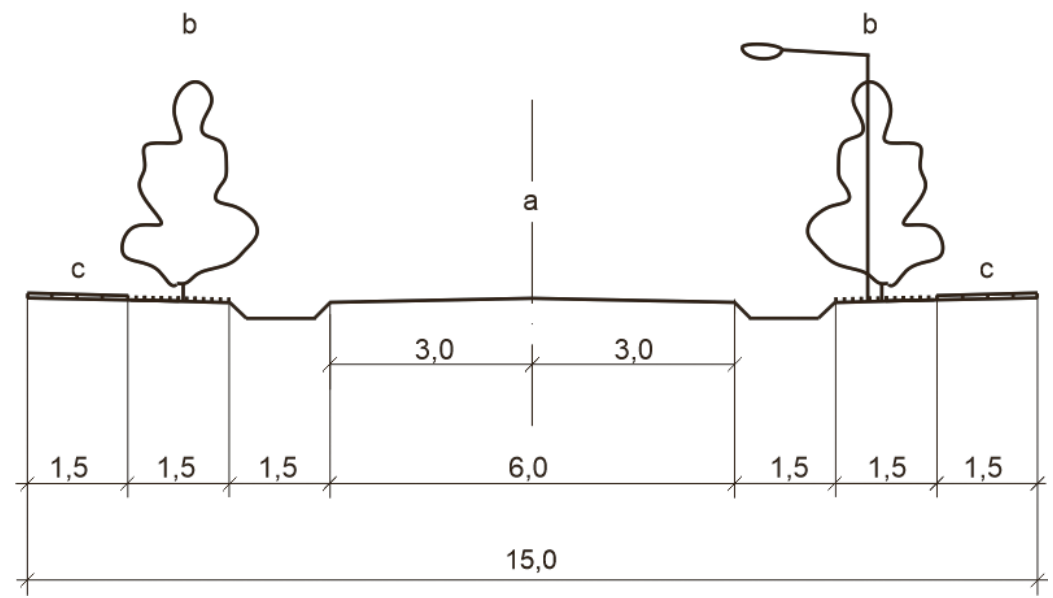

Fig. 4. Local street cross section:

$\mathrm{a}$ - pavement $[\mathrm{m}], \mathrm{b}$ - green planting zone $[\mathrm{m}], \mathrm{c}$ - sidewalk [m]

Source: according to State Construction Regulations [24]

For the territory under consideration, it is necessary to reallocate the existing land plots due to the need for extra $18,118 \mathrm{~m}^{2}$ to develop the residential block streets in accordance with regulations.

The research is based on the foundational principles of rural development: citizen participation and land management [17]. We have substantiated land reallotment options which take into account the main challenges and are presented to landowners for consideration.

\subsection{Land Reallotment by Means of the Cession of a Part of the Land Plot Area}

In Ukraine, a typical land reallotment option is the cession of a part of the land plot area for road improvements agreed by landowners. As a general matter, landowners accept it, provided the alteration of functional use results in the 
land plot value or profit increase. In this case, landowners have an incentive to alter the agricultural use due to the higher value of residential land plot, as opposed to the individual agriculture land plot value (as a rule, there is a choice of employment in a suburban zone). Such conclusions have been drawn by authors based on their calculations according to a method approved by the Government Resolution [25].

A number of key issues should be considered at the development of such projects. The development of a fair approach landowners to the specification of the area to be cessed acts in favour of agreement for all landowners (as a rule, in practice, a cession of proportionate or equal for all landowners land plot share is considered to be fair). An owner's personal use priorities are another key issue. For example, in case the landowner wishes to use their land solely for the cultivation of crops, they are not willing to give up a part of their land plot. In this case, it is reasonable to consider exchanging it for a land plot in another agricultural land mass.

The project territory is restricted by a road network which does not need to be improved. The suggested land reallotment option stipulates the cession of a part of the privately owned land plots (Fig. 5).

a)

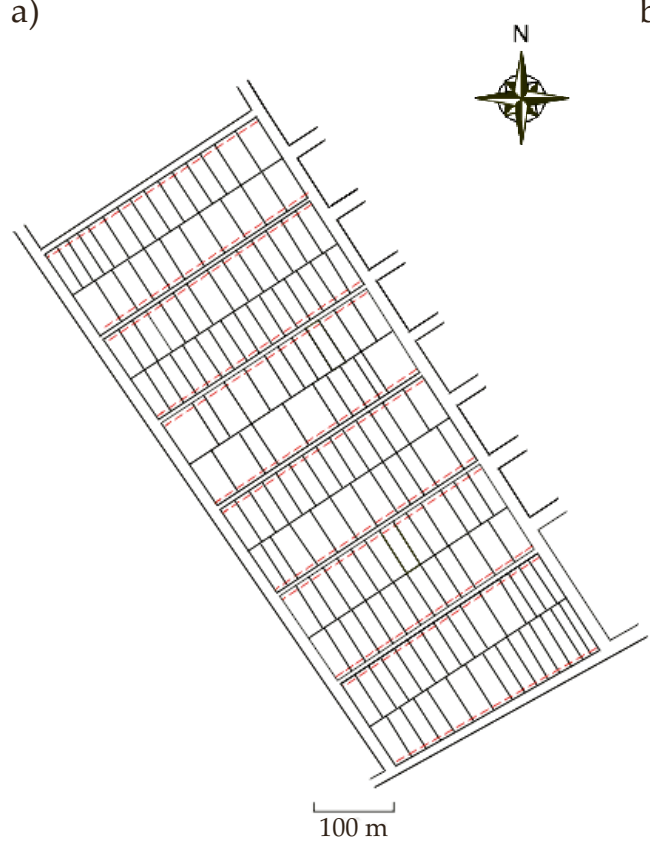

b)

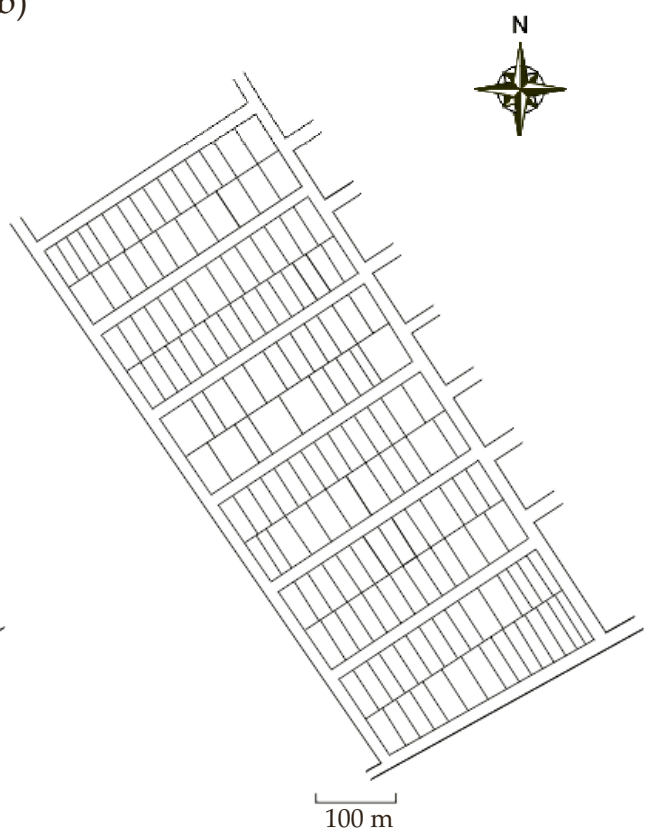

Land plots

Project street boundaries

Fig. 5. Reallotment option I:

a) project land mass before reallotment; b) project land mass after reallotment 
In order to cede an extra $18,118 \mathrm{~m}^{2}$, each landowner dedicates $112.5 \mathrm{~m}^{2}$ in average. For most $(65 \%)$ land plots within the project territory, the area is decreased by $85.7-110.6 \mathrm{~m}^{2}$ (Fig. 6). The average value of the expropriated area is $\$ 900.27$, total for the project territory: $\$ 144,944.00$.

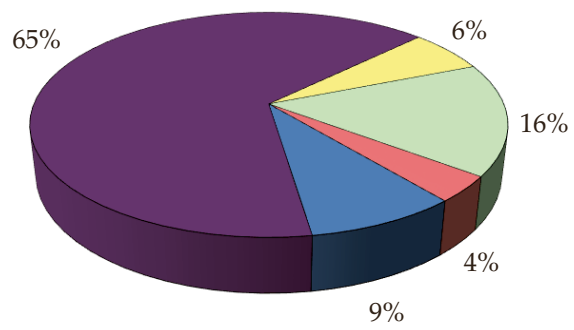

Area ceded, $\mathrm{m}^{2}$

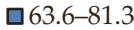

$\square 85.7-110.6$

口113.8-140.3

$\square 144.8-156.5$

口197.9-237.9

Fig. 6. Landowner ratio by area, ceded after reallotment within the project territory

At the development of the road network, each owner should dedicate approximately $8 \%$ of the land plot area (Fig. 7). For all land plots, almost the same part of the plot is ceded due to that the project land mass is restricted from two sides with streets which do not need to be improved (have a reserve for extension).

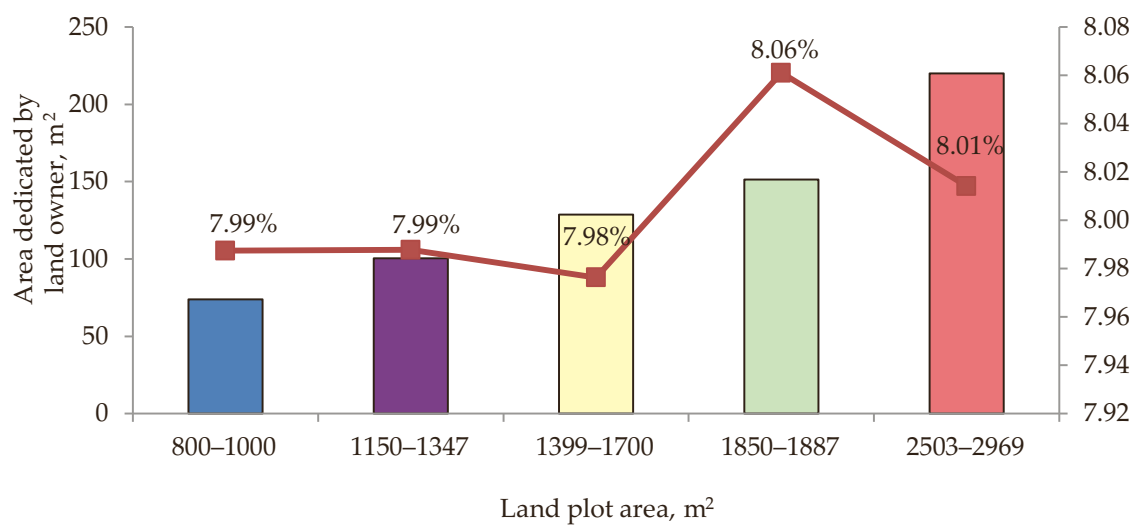

Fig. 7. Land plot share, ceded from land plots of various areas

In accordance with the reallotment project, placement and partly land plot boundaries are retained, however, owners lose a part of their land plot area. The project stipulates land plot subdivision with the owner's initiative. A part of land plot is dedicated for general use.

Let us analyse the alteration of land plot spatial characteristics after the reallotment and their impact on land use effectiveness and land plot value. 
First of all, the cession of a part of the land plot as the result of the alteration of the functional use of the project territory impacts the development perspectives of the newly created land plots. According to regulations in effect of Ukraine [24], the land plot area for the new homestead (residential) development should be at least $500 \mathrm{~m}^{2}$. The minimal area within the existing built-up area can be at least $400 \mathrm{~m}^{2}$. The mentioned areas can be considered to be the minimum required to meet the sanitary and fire regulations and requirements in the development. Otherwise, the area should be increased.

Due to the fact that the minimal agricultural land plot area was not specified at allocation and the division at inheritance was not restricted, some land plots can be smaller than the least possible for development. In this case, the plot cession is the only option in the course of the alteration of the territory's functional use.

Development and land plot use perspectives are also influenced by land plot configuration, which is changed after the cession of a part of the plot. According to State Construction Regulations of Ukraine, distance from residential buildings to main street building setback lines should be $6 \mathrm{~m}$, residential streets $-3 \mathrm{~m}$ [24]. The distance from the individual house walls with inhabited rooms and kitchen windows, as well as main entrance to other houses and household buildings, should be at least $6 \mathrm{~m}$ [24].

In this project, the configuration of newly created land plots depends on the regulations in effect. However, land plot configuration can be inappropriate either before the project, or as the result of the cession of a part of land plot.

The reallotment option provides for the utmost land plot boundaries possible. This approach is especially rewarding where there are buildings and structures on the land plot, since such a land plot is either specified as "inexchangeable" at the reallotment [26] or the need for compensation arises, which complicates the reallotment.

\subsection{Land Reallotment by Means of Redemption or Exchange of Selected Land Plots}

The area for streets is gained by the redemption of 13 land plots with the owners' consent (Fig. 8).

The key reallotment aspect is not the formation of the street network in accordance with the residential development requirements only, it is also about the improvement of the spatial characteristics of the land plot.

Land plots have the same area before and after reallotment within the project territory. This approach, unlike the previous one, provides the opportunity for the consolidation of land plots. In this project, the land plots of one landowner with the area of $800 \mathrm{~m}^{2}$ and $1170 \mathrm{~m}^{2}$ (Fig. 8) with the distance of $380 \mathrm{~m}$ between them, were consolidated. Where the designated use of agricultural land is altered to development, land consolidation has extra advantages.

After the reallotment, none of the land plots has a configuration which could restrict the development prospects and reduce value. 
a)

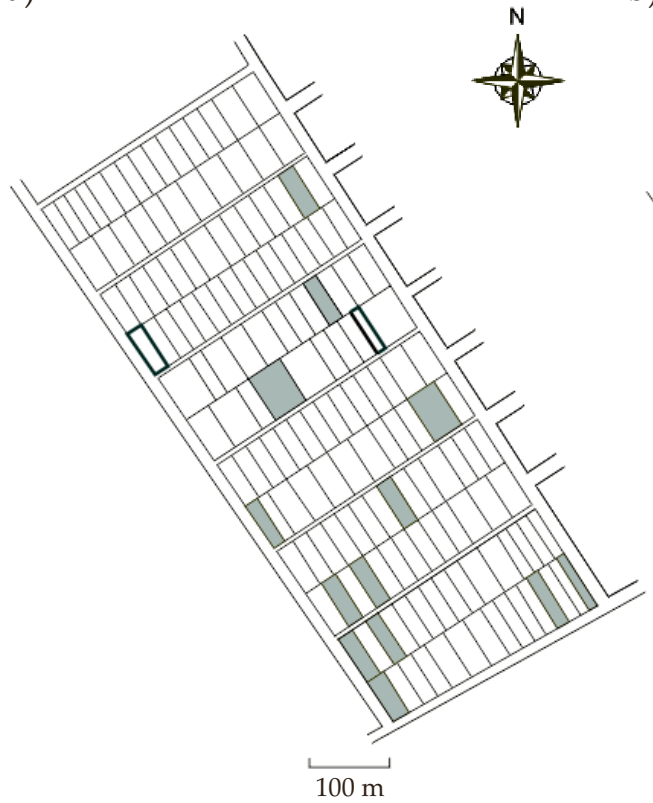

b)

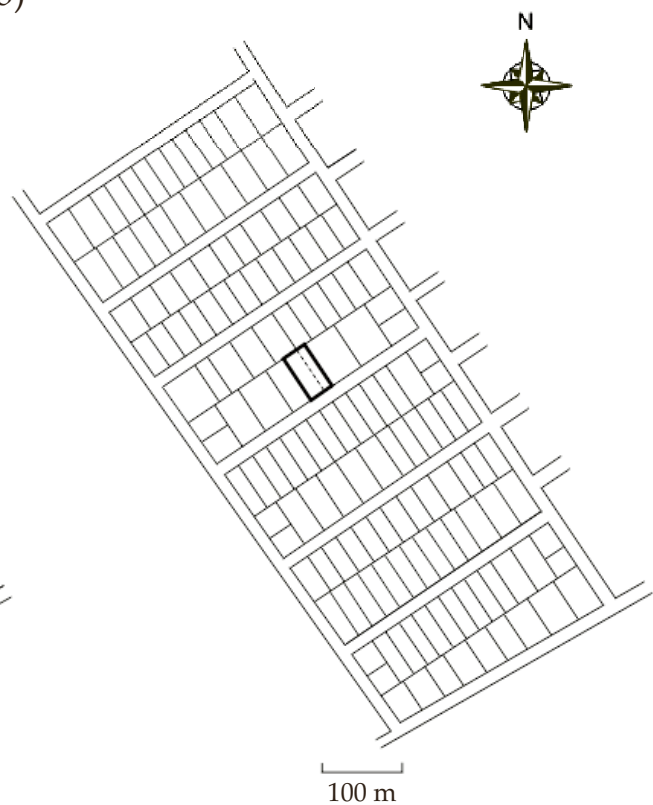

Land plots

Repurchased land plots

Consolidated land plots

Fig. 8. Reallotment option II:

a) project land mass before reallotment; b) project land mass after reallotment

Land plots with the area of up to $1000 \mathrm{~m}^{2}$. Had a configuration close to rectangular with the side ratio 1:4. Such a configuration complies with the requirements of agricultural activity, however, it impacts the development conditions and decreases the value of the land plot to be developed. The configuration of such land plots was improved over the course of reallotment.

The reallotment was carried out with the precondition of the least possible land plots placement alteration. After the reallotment, the same number of blocks was formed, as before reallotment, facilitating the formation of the optimal configuration of land plots.

\section{Results and Discussion}

The aggregate land plots value within the project territory is increased by $\$ 1,280,075$ for option I and $\$ 1,307,619$ for option II. In case of land plots redemption in the reallotment option II, it is necessary to pay the owners $\$ 270,885$. Land reallotment with land plots redemption is the most effective for land plots with the area of up to $1000 \mathrm{~m}^{2}$ (Fig. 9). 


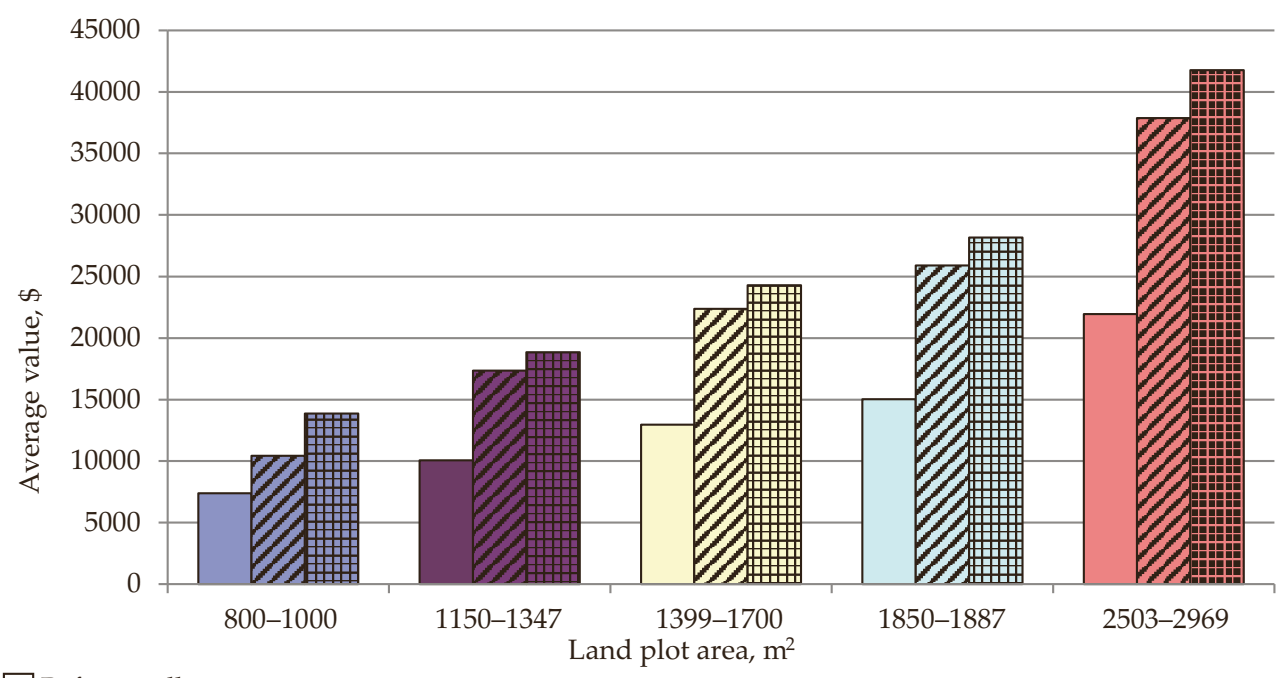

Before reallotment

Reallotment option I

囲 Reallotment option II

Fig. 9. Reallotment options comparison by land plot value

Each approach has its advantages and disadvantages which should be presented for consideration (Tab. 1).

Table 1. Reallotment options analysis

\begin{tabular}{|l|l|l||}
\hline $\begin{array}{l}\text { Analysis } \\
\text { criterion }\end{array}$ & \multicolumn{1}{|c|}{$\begin{array}{c}\text { Reallotment stipulating land plots } \\
\text { redemption (exchange) }\end{array}$} & \multicolumn{1}{c|}{$\begin{array}{c}\text { Reallotment stipulating land plots redemption } \\
\text { (exchange) }\end{array}$} \\
\hline \hline Strengths & $\begin{array}{l}\text { Reallotment stipulating the cession of } \\
\text { a part of land plot }\end{array}$ & $\begin{array}{l}\text { Opportunity for land consolidation. } \\
\text { Land plot value increase/absence of value } \\
\text { reduction }\end{array}$ \\
\hline Drawbacks & $\begin{array}{l}\text { Placement and most boundaries } \\
\text { retained. } \\
\text { Relatively fast implementation }\end{array}$ & $\begin{array}{l}\text { Redemption or exchange process organisation. } \\
\text { Need for boundaries demarcation at terrain. } \\
\text { Need for full documents re-issue. } \\
\text { Project realization in general and implementation } \\
\text { time depend on the consent of all landowners }\end{array}$ \\
\hline Risks & $\begin{array}{l}\text { The cession of a part of the land plot } \\
\text { and, respectively, loss of value. } \\
\text { Land plot configuration deterioration } \\
\text { in the course of reallotment }\end{array}$ & $\begin{array}{l}\text { Reallotment delay due to agreement with } \\
\text { landowners. } \\
\text { Complexity of the of exchange options search } \\
\text { or the redemption price substantiation }\end{array}$ \\
\hline Prospects & $\begin{array}{l}\text { Creation of land plots with } \\
\text { an area or configuration which } \\
\text { make it impossible to use the land } \\
\text { in accordance with its designated use. } \\
\text { Unfair, inequivalent cession of parts } \\
\text { of land plots within the land mass }\end{array}$ & $\begin{array}{l}\text { The development of legal regulations on } \\
\text { the landowners involvement into the process of } \\
\text { reallotment }\end{array}$ \\
\hline \multicolumn{2}{|l}{} \\
\hline
\end{tabular}


The choice of the reallotment option is still at the discretion of landowners and the territorial community. At present, there is no legislative regulation of reallotment. For example, the minimal share of landowners to make decision on reallotment is not specified.

\section{Conclusion}

The resolution of the challenging issue of the reallotment of land plots in the course of the residential development of a rural agricultural settlement has been suggested. The analysis of reallotment preconditions has been carried out, demands to land plots spatial characteristics at the designated use alteration have been scrutinized.

Taking into consideration the experience of the implementation of designated use alteration measures, two reallotment options have been presented to landowners for consideration. The first one involves the cession of a part of each land plot, the second - redemption (exchange) of some land plots.

The land reallotment approach stipulating the cession of a part of the land plot is reasonable when there are buildings or structures on the land plot or it is impossible to align the reallotment of the land plots for all landowners within the land mass in the environment of the absence of legislative regulation. At the practical realization, the most significant is the fact the formation of the new land plots of an individual owner does not depend on other landowners. On the contrary, the second approach stipulates the implementation of a complex reallotment for the whole project territory.

The reallotment approach stipulating the redemption of land plots (exchange) is more economically efficient. It is justified in case the determining factors are the following: need for land consolidation, the configuration of land plots is inappropriate for the designed land use, there is a possibility for compensation and landowners wish to sell (exchange) their land plots, infrastructure improvement is complicated.

\section{References}

[1] Pašakarnis G., Maliene V.: Towards sustainable rural development in Central and Eastern Europe: Applying land consolidation. Land Use Policy, vol. 27, no. 2, 2010, pp. 545-549.

[2] Palmer D., Munro-Faure P., Rembold F.: Land consolidation and rural development in Central and Eastern Europe. Fachbeiträge, vol. 129, no. 2, 2004, pp. 132-135.

[3] Lerman Z., Cimpoieş D.: Land consolidation as a factor for rural development in Moldova. Europe Asia Studies, vol. 58, 2006, pp. 439-455. https://doi. org/10.1080/09668130600601933. 
[4] Louwsma M., Lemmen C., Hartvigsen M., Hiironen J., Du Plessis J., Chen M., Laarakker P.M.: Land consolidation and land readjustment for sustainable development: the issues to be addressed. [in:] FIG Working Week 2017: Surveying the World of Tomorrow: From Digitalisation to Augmented Reality, 29 May-2 June 2017, Helsinki, Finland [conference paper]. http://www.fig.net/resources/proceedings/fig_proceedings/fig2017/papers/p06g/P06G_louwsma_lemmen_et_al_ 8973.pdf [access: 24.01.2021].

[5] Balla E.: Land Readjustment as a tool for Urban Development in Greece: the implementation gap between Laws, Policies and Practice. [in:] Symposium on Land Consolidation and Land Readjustment for Sustainable Development / LANDNET Workshop 2016, Apeldoorn, Netherlands [conference paper]. https://research.utwente.nl/ files/139199072/LC_2016_E.Balla_Greece_Final.pdf [access: 17.02.2021].

[6] Larsson G.: Land readjustment: A tool for urban development. Habitat International, vol. 21, no. 2, 1997, pp. 141-152.

[7] Souza F.F., Ochi T., Hosono A.: Land Readjustment: Solving Urban Problems through Innovative Approach. Japan International Cooperation Agency Research Institute, Tokyo 2018.

[8] Demetriou D., Stillwell J., See L.: Land consolidation in Cyprus: Why is an integrated planning and decision support system required? Land Use Policy, vol. 29, no. 1, 2012, pp. 131-142.

[9] Kolis K., Hiironen J., Riekkinen K., Vitikainen A.: Forest land consolidation and its effect on climate. Land Use Policy, vol. 61, 2017, pp. 536-542. https://doi. org/10.1016/j.landusepol.2016.12.004.

[10] Ayranci Y.: Re-allocation Aspects in Land Consolidation: A New Model and Its Application. Journal of Agronomy, vol. 6, 2007, pp. 270-277.

[11] Cay T., Ayten T., Iscan F.: Effects of different land reallocation models on the success of land consolidation projects: Social and economic approaches. Land Use Policy, vol. 27, no. 2, 2010, pp. 262-269. https://doi.org/10.1016/j.landusepol. 2009.03.001.

[12] Kik R.: A method for reallotment research in land development projects in the Netherlands. Agricultural Systems, vol. 33, no. 2, 1990, pp. 127-138.

[13] Moteva M.: Legal Conditions and Data Provision for Land Property Exchange in the Processes of Land Consolidation and Land Compensation in Bulgaria. Geomatics and Environmental Engineering, vol. 14, no. 2, 2020, pp. 59-71.

[14] Malashevskyi M., Palamar A., Malanchuk M., Bugaienko O., Tarnopolsky E.: The Opportunities for use the peer land exchange during land management in Ukraine. Geodesy and Cartography, vol. 42, no. 4, 2018, pp. 129-133.

[15] Hendricks A., Lisec A.: Land consolidation for large-scale infrastructure projects in Germany. Geodetski Vestnik, vol. 58, no. 1, 2013, pp. 46-68.

[16] Malashevskyi M., Palamar A., Malanchuk M., Bugaienko O.: The possibilities of sustainable land use formation in Ukraine. Geodesy and Cartography, vol. 46, no. 2, 2020, pp. 83-88. 
[17] Bavarian Ministry of Agriculture and Forestry: Rural Development in Bavaria. München 2006.

[18] Thomas J.: Land Consolidation as An Alternative to Compulsory Land Acquisition by Big Public Infrastructure Projects. Land Tenure Journal, vol. 1, no. 16, 2017, pp. 7-33.

[19] Thomas J.: Attempt on Systematization of Land Consolidation Approaches in Europe. Zeitschrift für Geodäsie, Geoinformation und Landmanagement, vol. 131, 2006, pp. 156-161.

[20] State Statistics Service of Ukraine: Number of Existing Population of Ukraine as of January 1, 2020. Kyiv 2020. http://database.ukrcensus.gov.ua/PXWEB2007/ ukr/publ_new1/2020/zb_chuselnist\%202019.pdf [access: 21.10.2020].

[21] Verkhovna Rada of Ukraine: Land code Ukraine as of October, 25, 2001 № 2768-III. Bulletin of Verkhovna Rada of Ukraine, no. 3-4, 2002, art. 27. https://zakon.rada.gov.ua/laws/show/2768-14 [access: 13.02.2021].

[22] Verkhovna Rada of Ukraine: The law of Ukraine of 22 May 2003 on land management. Bulletin of Verkhovna Rada of Ukraine, no. 36, 2003, art. 282. https://zakon.rada.gov.ua/laws/show/858-15 [access: 26.02.2021].

[23] The State Service of Ukraine for Geodesy, Cartography and Cadastre: Draft Law of Ukraine on Introducing Amendments to Certain Legislative Acts of Ukraine Concerning Land Consolidation. https://land.gov.ua/info/proekt-zakonuukrainy-pro-vnesennia-zmin-do-deiakykh-zakonodavchykh-aktiv-ukrainyz-pytan-konsolidatsii-zemel/ [access: 4.12.2020].

[24] Ministry of Construction and Architecture of Ukraine: State Construction Regulations B.2.4-1-94 Planning and building up rural settlements. Kyiv 1994. https://zakon.rada.gov.ua/rada/show/v0006307-94 [access: 13.11.2020].

[25] Cabinet of Ministers of Ukraine: Resolution on the Expert Monetary Evaluation of Land Plots. Official Gazette of Ukraine, no. 42, 2002, p. 144, art. 1941. https://zakon.rada.gov.ua/laws/show/1531-2002 [access: 10.12.2020].

[26] Yimer F.A.: Fit-for-purpose Land Consolidation: An Innovative Tool for Re-allotment in Rural Ethiopia. Enschede, The Netherlands 2014. 